\title{
Growth Arrest-Specific Protein 1
}

National Cancer Institute

\section{Source}

National Cancer Institute. Growth Arrest-Specific Protein 1. NCI Thesaurus. Code C106454.

Growth arrest-specific protein 1 (345 aa, $36 \mathrm{kDa}$ ) is encoded by the human GAS1 gene. This protein plays a role in both cell cycle arrest and cell growth suppression. 